\title{
Estimating the Risk of ABO Hemolytic Disease of the Newborn in Lagos
}

\author{
Alani Sulaimon Akanmu, Olufemi Abiola Oyedeji, \\ Titilope Adenike Adeyemo, and Ann Abiola Ogbenna \\ Department of Hematology \& Blood Transfusion, Faculty of Clinical Sciences, College of Medicine, University of Lagos, \\ PMB 12003, Lagos, Nigeria
}

Correspondence should be addressed to Olufemi Abiola Oyedeji; drfemoyedeji@yahoo.com

Received 21 May 2015; Revised 29 August 2015; Accepted 3 September 2015

Academic Editor: Silvano Wendel

Copyright (c) 2015 Alani Sulaimon Akanmu et al. This is an open access article distributed under the Creative Commons Attribution License, which permits unrestricted use, distribution, and reproduction in any medium, provided the original work is properly cited.

Background. ABO hemolytic disease of the newborn is the most common hemolytic consequence of maternofetal blood group incompatibility restricted mostly to non-group-O babies of group $\mathrm{O}$ mothers with immune anti-A or anti-B antibodies. Aim. We estimated the risk of $\mathrm{ABO} \mathrm{HDN}$ with view to determining need for routine screening for $\mathrm{ABO}$ incompatibility between mother and fetus. Materials and Methods. Prevalence of ABO blood group phenotypes in blood donors at the donor clinic of the Lagos University Teaching Hospital and arithmetic methods were used to determine population prevalence of ABO genes. We then estimated proportion of pregnancies of group $\mathrm{O}$ mothers carrying a non-group-O baby and the risk that maternofetal $\mathrm{ABO}$ incompatibility will cause clinical ABO HDN. Results. Blood from 9138 donors was ABO typed. 54.3\%, 23\%, 19.4\%, and 3.3\% were blood groups $\mathrm{O}, \mathrm{A}, \mathrm{B}$, and $\mathrm{AB}$, respectively. Calculated gene frequencies were $0.1416,0.1209$, and 0.7375 for $\mathrm{A}, \mathrm{B}$, and $\mathrm{O}$ genes, respectively. It was estimated that $14.3 \%$ of deliveries will result in a blood group $\mathrm{O}$ woman giving birth to a child who is non-group-O. Approximately $4.3 \%$ of deliveries are likely to suffer ABO HDN with $2.7 \%$ prone to suffer from moderately severe to severe hemolysis.

\section{Introduction}

$\mathrm{ABO}$ hemolytic disease of the newborn (ABO HDN) is the most common maternofetal blood group incompatibility. Unlike the rhesus disease, it is usually a problem of the neonate rather than the fetus. $\mathrm{ABO} \mathrm{HDN}$ is restricted almost entirely to group $\mathrm{A}$ or $\mathrm{B}$ babies born to group $\mathrm{O}$ mothers with immune anti-A or anti-B antibodies.

ABO HDN is caused by IgG (immune) maternal antibodies which have the ability to cross the placental barrier. A high titre of these immune antibodies may not present with adverse effects in utero as A and B antigens are present on cells of all other tissues and body fluid and not only on red cells. The presence of these antigens helps to protect the incompatible fetal red cells by neutralizing the transferred maternal antibody with small amounts of antibody reacting directly with the fetal red cells [1]. The red cells which are sensitized by the antibodies are destroyed by macrophages in the fetal spleen with consequent hyperbilirubinaemia [2].
ABO-HDN in literature is described as a condition having a very low incidence in the population and characterized by a benign evolution because of a mild degree of hemolysis $[3,4]$. Anaemia is rare with the main clinical problem being jaundice. Severe hemolysis and anaemia requiring exchange blood transfusion have however been reported [5]. Early detection and treatment of neonatal hyperbilirubinaemia is important in prevention of bilirubin-induced encephalopathy in the affected children [6].

The above statements, however, are not valid for all populations. Studies have revealed that statistically, mother and infant are $\mathrm{ABO}$-incompatible in one of every five pregnancies among Caucasians $[7,8]$. The incidence of ABO HDN in the United Kingdom is about $2 \%$ of all births, but severe hemolytic disease occurs in only $0.03 \%$ of births [9]. The incidence of $\mathrm{ABO} \mathrm{HDN}$ in Blacks [10] is said to be higher than in Caucasians [11-13]. This is due to the higher prevalence and titres of immune anti-A and anti-B antibodies in the Black population [14-18]. 
TABLE 1: ABO typing of blood donors at the Lagos University Teaching Hospital University Teaching Hospital.

\begin{tabular}{lccccccccc}
\hline Blood group & O POS. & O Neg. & A POS. & A Neg. & B POS. & B Neg. & AB POS. & AB Neg. & Total \\
\hline Number of donors & 4679 & 283 & 2001 & 97 & 1677 & 94 & 281 & 26 & $\mathbf{9 1 3 8}$ \\
\hline$\%$ & 51.2 & 3.1 & 21.9 & 1.1 & 18.4 & 1.0 & 3.0 & 0.3 & $\mathbf{1 0 0}$ \\
\hline
\end{tabular}

POS.: positive.

Neg.: negative.

Routine antenatal antibody screening tests (indirect Coombs test) do not routinely include screening for $\mathrm{ABO}$ HDN. Diagnosis is usually made by investigation of a newborn baby who has developed jaundice during the first day of life. Routine screening for ABO incompatibility between mother and fetus is not performed and according to Han et al. it is not cost effective to routinely screen for $\mathrm{ABO}$ incompatibility in the Asian population [19].

The prevalence of immune anti-A and anti-B antibodies and the population and gene frequencies of the various $\mathrm{ABO}$ blood groups are useful in predicting an estimate of children born by blood group $\mathrm{O}$ women married to non-group-O husbands who are at risk of developing ABO HDN.

This study aims at estimating the risk of ABO HDN in our population with a view to determining whether there is the need for routine screening since the incidence of $\mathrm{ABO} \mathrm{HDN}$ is expected to be higher in Blacks.

\section{Subjects and Methods}

We determined the prevalence of $\mathrm{ABO}$ blood types among 9138 blood donors at Lagos University Teaching Hospital by collating the data of all donors over a one-year period. Arithmetical methods based on Hardy Weinberg equilibrium were then used to determine population prevalence of different $\mathrm{ABO}$ genes using the phenotype data obtained from $\mathrm{ABO}$ typing of blood donors (Appendix A).

The population prevalence of hemolysins in Lagos [20] in combination with the obtained $\mathrm{ABO}$ gene frequencies was used to calculate the likelihood of scenario where a nonblood-group-O baby will be born to a blood group $\mathrm{O}$ mother with immune $\mathrm{ABO}$ antibodies (Appendix B). These were then used to arrive at an estimate of the incidence of ABO HDN within the population.

\section{Results}

A total of 9138 blood donors were ABO blood group typed. 4962 (54.3\%) were blood group O. Blood group A was slightly more prevalent $(23.0 \%)$ than blood group B (19.4\%). AB blood group constituted only 3.3\% (Table 1).

The calculated population prevalence of the A, B, and $\mathrm{O}$ genes in Lagos is $0.1416,0.1209$, and 0.7375 , respectively (details of calculations are presented in Appendix A).

The calculated probability of a blood group $\mathrm{O}$ woman giving birth to a child who is non-group-O phenotype is $14.3 \%$ of deliveries in Lagos (details of calculations are presented in Appendix B).

With a prevalence of anti-A and anti-B hemolysins in blood group O individuals of $30.3 \%$ and with $18.6 \%$ of blood group $\mathrm{O}$ donors having significant visual titres, approximately $4.3 \%$ of deliveries (30.3\% of $14.3 \%$ deliveries) are likely to suffer ABO HDN with $2.7 \%$ of deliveries (18.6\% of $14.3 \%$ deliveries) prone to suffer from moderately severe to severe hemolysis.

\section{Discussion}

The incidence of severe neonatal jaundice within the first few hours of life (bilirubin above $10 \mathrm{mg} / 100 \mathrm{~mL}$ ) is fairly common with a significant number requiring exchange transfusions. However, the number of cases that are due to hemolysis from $\mathrm{ABO}$ incompatibility between mother and fetus have not yet been established. A 1 in 5 chance of ABO incompatibility between fetal red cells and maternal serum exists but the incidence of $\mathrm{ABO} \mathrm{HDN}$ elsewhere is said to be uncommon occurring in $2 \%$ of all births $[5,9]$. Race has however been shown to have an effect on the incidence and severity of $A B O$ HDN with a higher incidence and severity being observed among Blacks [10] and Latin Americans [7]. Thus we can expect the incidence and severity of $\mathrm{ABO} \mathrm{HDN}$ to be higher in Nigeria.

Blood group O individuals were $54.3 \%$ of the donor population which is consistent with those found in an earlier population study by Ahmed et al. in Lagos State [21]. As it can be assumed that sex factor has no influence on $\mathrm{ABO}$ gene inheritance and blood group distribution, then 54.3\% of females in Lagos can be assumed to be blood group $\mathrm{O}$.

From results obtained in this study using the gene frequencies of the $\mathrm{ABO}$ blood group antigens and then calculating the probabilities of a blood group $\mathrm{O}$ woman marrying a non-group-O man and having a non-group-O child, the incidence of $\mathrm{ABO}$ incompatible pregnancies in the population with the mother being blood group $\mathrm{O}$ is $14.3 \%$. This is similar to results obtained by Cariani et al. [7] in Venezuela and what has been reported for anglosaxon countries [22]. This is due to the similar frequency of blood group $\mathrm{O}$ in the studied populations.

Anti-A and anti-B hemolysins prevalence in the study population is $30.3 \%$ with $18.6 \%$ having significant visual titres of 8 and above [20]. From calculations, $4.3 \%$ of deliveries in Lagos (30.3\% of $14.3 \%$ deliveries) are likely to suffer ABO $\mathrm{HDN}$. This is consistent with reports which have found that the incidence of $\mathrm{ABO} \mathrm{HDN}$ is higher in Blacks than in Caucasians [11-13] and is double that of the figures obtained for the United Kingdom [9]. This higher finding can be explained by the higher prevalence of hemolysins in Black population. Visual titres of hemolysins of 8 and above have been associated with significant in vivo hemolysis [17, 23]. Assuming those with significant visual titre as being capable 
of leading to severe ABO HDN, potentially $2.7 \%$ of deliveries (18.6\% of $14.3 \%$ deliveries) will have moderately severe to severe ABO HDN. This finding is considerably higher than in the United Kingdom where severe hemolytic disease occurs in only $0.03 \%$ of births [9].

Routine screening for $\mathrm{ABO}$ incompatibility is presently not performed in Lagos University Teaching Hospital with most babies discharged as soon as possible after delivery. Also, there is no test that is of high predictive value for severe $\mathrm{HDN}$. It can however be suggested that hemolysis from $\mathrm{ABO}$ $\mathrm{HDN}$ can be more severe amongst Nigerian neonates whose mothers tend to have higher prevalence and titres of immune anti-A and anti-B antibodies from several studies [14-18]. Thus, there may be a case for routine screening for immune antibodies in pregnant blood group $\mathrm{O}$ women to monitor fetuses that may be at risk.

As routine testing for hemolysins is not performed in this environment, blood group $\mathrm{O}$ women with suspected high immune antibody titre or with a history of $\mathrm{ABO}$ incompatibility in a previous pregnancy may also require monitoring of their neonates.

\section{Conclusion}

The estimated risk of $\mathrm{ABO} \mathrm{HDN}$ among non-group-O offspring of blood group $\mathrm{O}$ women is $4.3 \%$ of all deliveries in Lagos University Teaching Hospital. 2.7\% of babies ABO incompatible with their mothers are at risk of moderately severe to severe HDN. With this finding, it may not be cost effective to routinely screen for ABO HDN. However, best practices for detecting neonatal jaundice need to be put in place and, if severe neonatal jaundice occurs in a setting of $\mathrm{ABO}$ incompatibility, intravenous immunoglobulin which usually avoids the invasive procedure of an exchange transfusion should be considered.

\section{Appendices}

\section{A. Arithmetical Calculation of Population Prevalence of ABO Genes from Phenotype Data}

From Figure 1, the gene, genotype, and phenotype frequencies of the ABO blood groups can be deduced.

According to Mourant et al. [24], square e-f-g-h in Figure 1 has a breadth and length of unity such that the area of the square is also unity. If along the length and breadth we have genes $\mathrm{O}, \mathrm{A}$, and $\mathrm{B}$ representing the $\mathrm{ABO}$ genes of both parents of a child, the possible genotypes of the offspring are represented in the smaller boxes within the bigger square and these possible genotypes can easily be derived from expansion of binomial $(\mathrm{A}+\mathrm{B}+\mathrm{O})^{2}$ to give $\left(A^{2}+B^{2}+O^{2}+\right.$ $2 A B+2 A O+2 B O)$.

From this expansion, we can estimate the population prevalence of different $\mathrm{ABO}$ genotypes in a given population if the prevalence of some of the genotypes is known particularly the genotype that can easily be derived from knowing the prevalence of the phenotype:

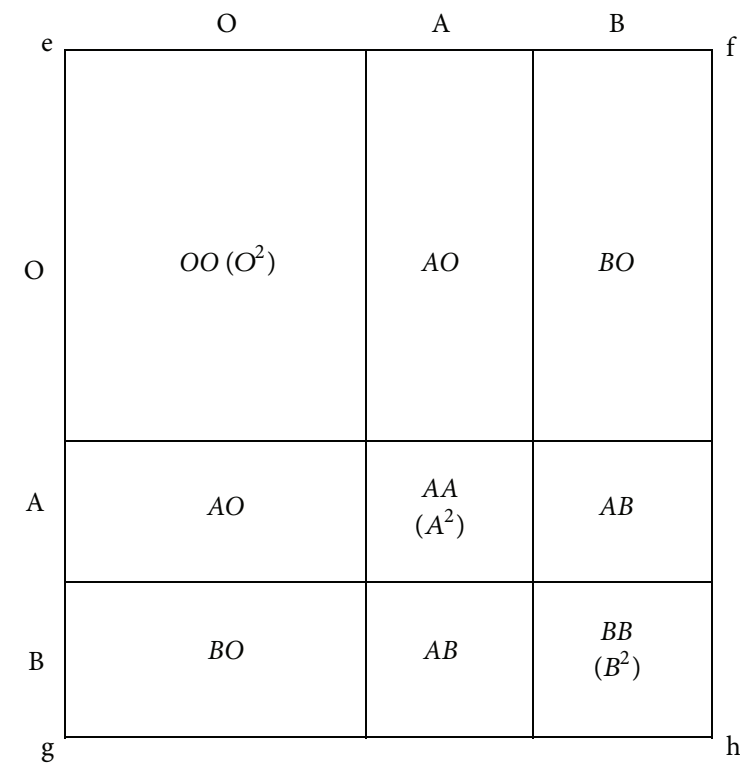

FIGURE 1: Deducing the gene, genotype, and phenotype frequencies of the $\mathrm{ABO}$ blood in a population.

$$
\begin{aligned}
& \text { Phenotype } \mathrm{O} \text { has genotype } O O(\mathrm{O}=O O) \text {. } \\
& \text { Phenotype } \mathrm{A} \text { has genotype } A A+A O(\mathrm{~A}=A A+A O) \text {. } \\
& \text { Phenotype } \mathrm{B} \text { has genotype } B B+B O(\mathrm{~B}=B B+B O) . \\
& \text { Phenotype } \mathrm{AB} \text { has genotype } A B(\mathrm{AB}=A B) .
\end{aligned}
$$

It is conventional to represent genes $\mathrm{A}, \mathrm{B}$, and $\mathrm{O}$ with letters $p, q$, and $r$, respectively.

Thus, genotype $A A$ prevalence is a square of the prevalence of gene $\mathrm{A}$ in a given population; that is,

$$
A A=A^{2}=p^{2} .
$$

Similarly,

$$
\begin{gathered}
B B=B^{2}=q^{2}, \\
O O=O^{2}=r^{2} .
\end{gathered}
$$

From Figure 1 or the expansion of the binomial $(\mathrm{A}+\mathrm{B}+\mathrm{O})^{2}$ to give $\left(A^{2}+B^{2}+O^{2}+2 A B+2 A O+2 B O\right)$ prevalence of genotype $A O$ will be given by

$$
A O=2 A O=2 p r .
$$

Similarly,

$$
\begin{aligned}
& B O=2 B O=2 q r, \\
& A B=2 A B=2 p q .
\end{aligned}
$$

Equations (A.1) to (A.5) shall now be used to calculate the prevalence of the $\mathrm{ABO}$ genes in a given population.

A gene occurs in genotypes $A A$ and $A O$. Thus prevalence of A gene is given by

$$
\mathrm{A}=(A A+A O)=\left(p^{2}+2 p r\right) .
$$


Similarly,

$$
\mathrm{B}=(B B+B O)=\left(q^{2}+2 q r\right)
$$

Adding (A.6) and (A.3), we have,

$$
\begin{aligned}
(\mathrm{A}+\mathrm{O})= & p^{2}+2 p r \\
& +r^{2} \text { (Hardy Weinberg Equation) } .
\end{aligned}
$$

Extracting square root of (A.8),

$$
\sqrt{\mathrm{A}+\mathrm{O}}=(p+r)
$$

Since $p+q+r=1$ (i.e., sum of prevalence of $\mathrm{A}, \mathrm{B}$, and $\mathrm{O}$ genes in a given population),

$$
q=1-(p+r)=1-\sqrt{\mathrm{A}+\mathrm{O}} .
$$

Similarly,

$$
p=1-(q+r)=1-\sqrt{\mathrm{B}+\mathrm{O}} .
$$

From (A.3), we can derive that prevalence of gene $\mathrm{O}$ that is, $r$, is

$$
r=\sqrt{O^{2}}
$$

Applying the above equations to the prevalence of ABO blood group phenotypes from the record of 9138 blood donors at the Lagos University Teaching Hospital donor clinic we estimate the following.

4962 of 9138 (54.3\%) donors were blood group O, 23.0\% (2098) were blood group A, 19.4\% (1771) were blood group B, and 3.3\% (307) were blood group $\mathrm{AB}$.

From (A.11) $p=1-\sqrt{\mathrm{B}+\mathrm{O}}$ and using the values above,

$$
\begin{aligned}
p & =1-\sqrt{0.194+0.543}=1-\sqrt{0.737}=1-0.8585 \\
& =0.1415
\end{aligned}
$$

Therefore population frequency for A gene $=p=0.1415$.

From (A.10), also using the above values,

$$
\begin{aligned}
q & =1-\sqrt{0.23+0.543}=1-\sqrt{0.773}=1-0.8792 \\
& =0.1208
\end{aligned}
$$

Therefore population frequency for B gene $=q=0.1208$.

From (A.3), we can say that

$$
O^{2}=r^{2}=0.543
$$

Therefore population frequency for $\mathrm{O}$ gene $=\sqrt{\mathrm{O}^{2}}=$ $\sqrt{0.543}=0.7369$.

Thus $r=0.7369$.
A.1. Corrected ABO Gene Frequencies. According to Bernstein [25] the sum total of $p, q$, and $r$ does not usually sum up to 1 . The $p, q$, and $r$ estimates need to be corrected using a quantity $D$ which is defined as

$$
D=1-(p+q+r) \text {. }
$$

From addition above, $(p+q+r)=0.1415+0.1208+0.7369=$ 0.9992. Consider

$$
D=1-0.9992=0.0008 \text {. }
$$

The corrected frequencies for $p\left(p_{c}\right), q\left(q_{c}\right)$, and $r\left(r_{c}\right)$, according to Bernstein, are

$$
\begin{aligned}
& p_{c}=\frac{p}{1-D}=\frac{0.1415}{1-0.0008}=\frac{0.1415}{0.9992}=0.1416, \\
& q_{c}=\frac{q}{1-D}=\frac{0.1208}{1-0.0008}=\frac{0.1208}{0.9992}=0.1209, \\
& r_{c}=\frac{r}{1-D}=\frac{0.7369}{1-0.0008}=\frac{0.7369}{0.9992}=0.7375 .
\end{aligned}
$$

Thus the calculated gene frequencies were $0.1416,0.1209$, and 0.7375 for the $\mathrm{A}, \mathrm{B}$, and $\mathrm{O}$ genes, respectively.

\section{B. Calculating Likelihood of Scenario Where a Non-Blood-Group-O Child Is Born to a Blood Group $O$ Mother}

For ABO hemolytic disease of the newborn to occur, a blood group $\mathrm{O}$ woman must be married to a non-group-O man and have an offspring who is non-blood-group-O.

The probability will be the summation of probability of occurrence of blood group genotypes $A A, B B, A O, B O$, and $A B$ husband being married to group $O O$ genotype wife resulting in an offspring with non-group-O gene.

Using the gene frequencies calculated above, one has the following.

The probability that an $O O$ genotype woman will be married to $A A$ genotype is the product of frequency of $O O$ genotype and frequency of $A A$ genotype:

$$
A A=r^{2} \times p^{2} .
$$

Therefore,

$$
A A=0.7375^{2} \times 0.1416^{2}=0.010906 .
$$

Similarly,

$$
B B=0.7375^{2} \times 0.1209^{2}=0.007950 .
$$

The probability that an $O O$ genotype woman will be married to $A O$ genotype man will be given by

$$
A O=r^{2} \times 2 p r .
$$

The probability that the child will inherit the A gene from the father is half. Therefore the probability that an $A O$ man and an $O O$ woman will have an $A O$ child will be given by

$$
\begin{aligned}
& A O=\frac{\left(r^{2} \times 2 p r\right)}{2}=r^{2} \times p r, \\
& A O=0.7375^{2} \times 0.1416 \times 0.7375=0.056800 .
\end{aligned}
$$


Similarly,

$$
B O=0.7375^{2} \times 0.1209 \times 0.7375=0.048497 .
$$

The probability that $O O$ genotype woman will be married to $A B$ genotype man and the child will have either $\mathrm{A}$ or $\mathrm{B}$ gene is given by

$$
\begin{aligned}
& A B=r^{2} \times 2 p q, \\
& A B=0.7375^{2} \times 2 \times 0.1416 \times 0.1209=0.018623 .
\end{aligned}
$$

The sum of all the probabilities $=0.142776$.

Therefore, $14.3 \%$ of deliveries in Lagos University Teaching Hospital University Teaching Hospital will result in a woman whose blood group is $\mathrm{O}$ giving birth to a child who has a non-group-O phenotype.

\section{Conflict of Interests}

The authors declare that there is no conflict of interests regarding the publication of this paper.

\section{References}

[1] R. Ottenberg, "Studies in isoagglutination: I. Transfusion and the question of intravascular agglutination," The Journal of Experimental Medicine, vol. 13, no. 4, pp. 425-438, 1911.

[2] A. G. Hadley, "Laboratory assays for predicting the severity of haemolytic disease of the fetus and newborn," Transplant Immunology, vol. 10, no. 2-3, pp. 191-198, 2002.

[3] I. Halbrecht, "Icterus precox. Further studies on its frequency, etiology, prognosis and the blood chemistry of the cord blood," The Journal of Pediatrics, vol. 39, no. 2, pp. 185-190, 1951.

[4] D. Voak and C. C. Bowley, "A detailed serological study on the prediction and diagnosis of $\mathrm{ABO}$ haemolytic disease of the newborn (ABO-HD)," Vox Sanguinis, vol. 17, no. 5, pp. 321-348, 1969.

[5] B. K. Gilja and V. P. Shah, "Hydrops fetalis due to ABO incompatibility," Clinical Pediatrics, vol. 27, no. 4, pp. 210-212, 1988.

[6] A. Petrova, R. Mehta, G. Birchwood, B. Ostfeld, and T. Hegyi, "Management of neonatal hyperbilirubinemia: pediatricians' practices and educational needs," BMC Pediatrics, vol. 6, article 6, 2006

[7] L. Cariani, E. L. Romano, N. Martinez et al., "ABO-haemolytic disease of the newborn (ABO-HDN): factors influencing its severity and incidence in Venezuela," Journal of Tropical Pediatrics, vol. 41, no. 1, pp. 14-21, 1995.

[8] M. S. Kennedy and A. Waheed, "Hemolytic disease of the newborn and fetus," in Modern Blood Banking and Transfusion Practices, D. Harmening, Ed., pp. 431-432, F.A. Davis Company, Philadelphia, Pa, USA, 4th edition, 1999.

[9] M. McDonnell, S. Hannam, and S. P. Devane, "Hydrops fetalis due to ABO incompatibility", Archives of Disease in Childhood: Fetal and Neonatal Edition, vol. 78, no. 3, pp. F220-F221, 1998.

[10] G. H. Vos, M. Adhikari, and H. M. Coovadia, "A study of ABO incompatibility and neonatal jaundice in black South African newborn infants," Transfusion, vol. 21, no. 6, pp. 744-749, 1981.
[11] K. J. Peevy and H. J. Wiseman, "ABO hemolytic disease of the newborn: evaluation of management and identification of racial and antigenic factors," Pediatrics, vol. 61, no. 3, pp. 475-478, 1978.

[12] H. N. Kirkman Jr., "Further evidence for a racial difference in frequency of $\mathrm{ABO}$ hemolytic disease," The Journal of Pediatrics, vol. 90, no. 5, pp. 717-721, 1977.

[13] K. A. Bucher, A. M. Patterson Jr., R. C. Elston, C. A. Jones, and H. N. Kirkman Jr., "Racial difference in incidence of ABO hemolytic disease," American Journal of Public Health, vol. 66, no. 9, pp. 854-858, 1976.

[14] A. G. Kulkarni, R. Ibazebe, and A. F. Fleming, "High frequency of anti-A and anti-B haemolysins in certain ethnic groups of Nigeria," Vox Sanguinis, vol. 48, no. 1, pp. 39-41, 1985.

[15] K. E. Onwukeme and O. U. Nanna, "Frequency of anti-A and anti-B hemolysins in Nigerians living in Jos," Nigerian Medical Practitioner, vol. 20, article 29, 1990.

[16] S. Worlledge, S. E. Ogiemudia, C. O. Thomas, B. N. Ikoku, and L. Luzzatto, "Blood group antigens and antibodies in Nigeria," Annals of Tropical Medicine and Parasitology, vol. 68, no. 3, pp. 249-264, 1974

[17] A. S. David-West, "Blood transfusion and blood bank management in a tropical country," Clinics in Haematology, vol. 10, no. 3, pp. 1013-1028, 1981.

[18] H. O. Olawumi and P. O. Olatunji, "Prevalence and titre of alpha and beta haemolysins in blood group 'O' donors in Ilorin," African Journal of Medicine and Medical Sciences, vol. 30, no. 4, pp. 319-321, 2001.

[19] P. Han, R. Kiruba, R. Ong, R. Joseph, K. L. Tan, and H. B. Wong, "Haematolytic disease due to $\mathrm{ABO}$ incompatibility: incidence and value of screening in an Asian population," Australian Paediatric Journal, vol. 24, no. 1, pp. 35-38, 1988.

[20] O. Oyedeji, T. Adeyemo, A. Ogbenna, and A. Akanmu, "Prevalence of anti-A and anti-B hemolysis among blood group $\mathrm{O}$ donors in Lagos," Nigerian Journal of Clinical Practice, vol. 18, no. 3, pp. 328-332, 2015.

[21] O. A. Ahmed, P. U. Agomo, D. K. Olukoya, and G. J. F. Esan, "The prevalence of $\mathrm{ABO}$ blood group antigens and antibodies in Lagos State, Nigeria," African Journal of Medicine and Medical Sciences, vol. 22, no. 3, pp. 49-53, 1993.

[22] P. L. Mollison, C. P. Engelfriet, and M. Contreras, Blood Transfusion in Clinical Medicine, Blackwell Scientific Publications, Oxford, UK, 8th edition, 1987.

[23] D. G. Saphire, N. S. Rudolph, S. M. Hackleman, and W. H. Stone, "The effect of age on the level of human $\mathrm{ABO}$ blood group antibodies," Aging, vol. 5, no. 3, pp. 177-184, 1993.

[24] A. E. Mourant, A. C. Kopec, and K. Domaniewska-Sobczak, "Gene frequency calculation," in The Distribution of Human Blood Groups and Other Polymorphisms, pp. 47-61, Oxford University Press, London, UK, 2nd edition, 1976.

[25] F. Bernstein, "Forgesetzte Untersuchungen aus der Theorie der Blutgruppen," Zeitschrift für Induktive Abstammungs- und Vererbungslehre, vol. 56, pp. 233-272, 1930. 


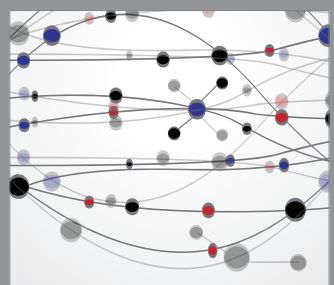

The Scientific World Journal
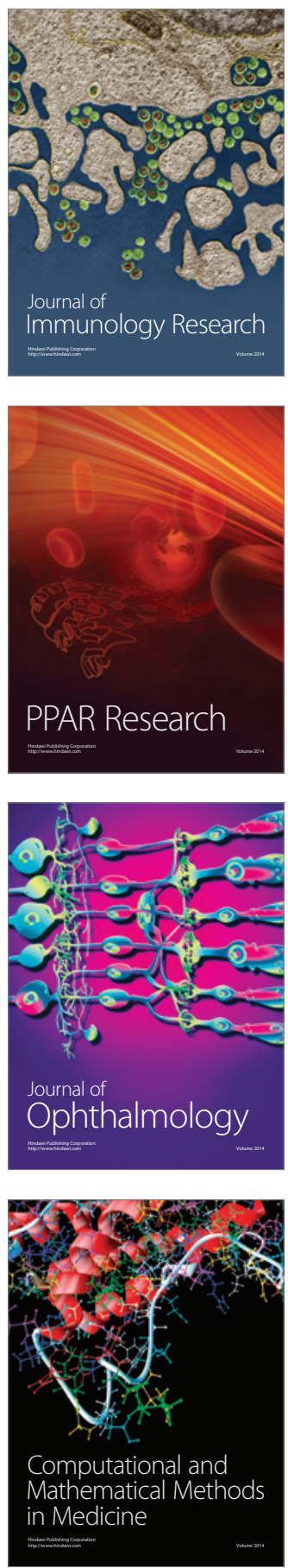

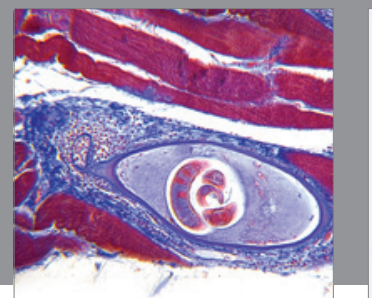

Gastroenterology

Research and Practice
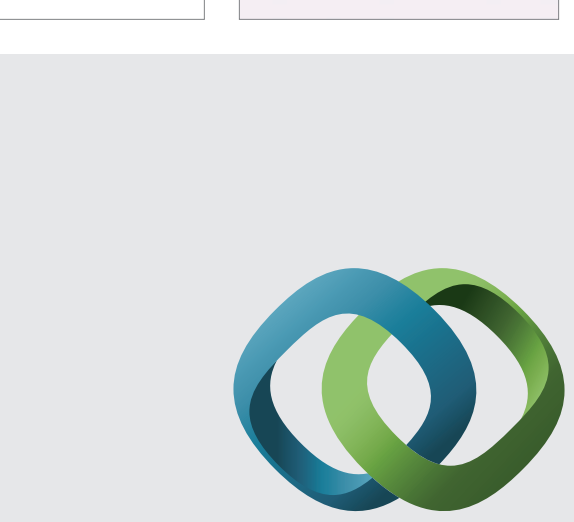

\section{Hindawi}

Submit your manuscripts at

http://www.hindawi.com
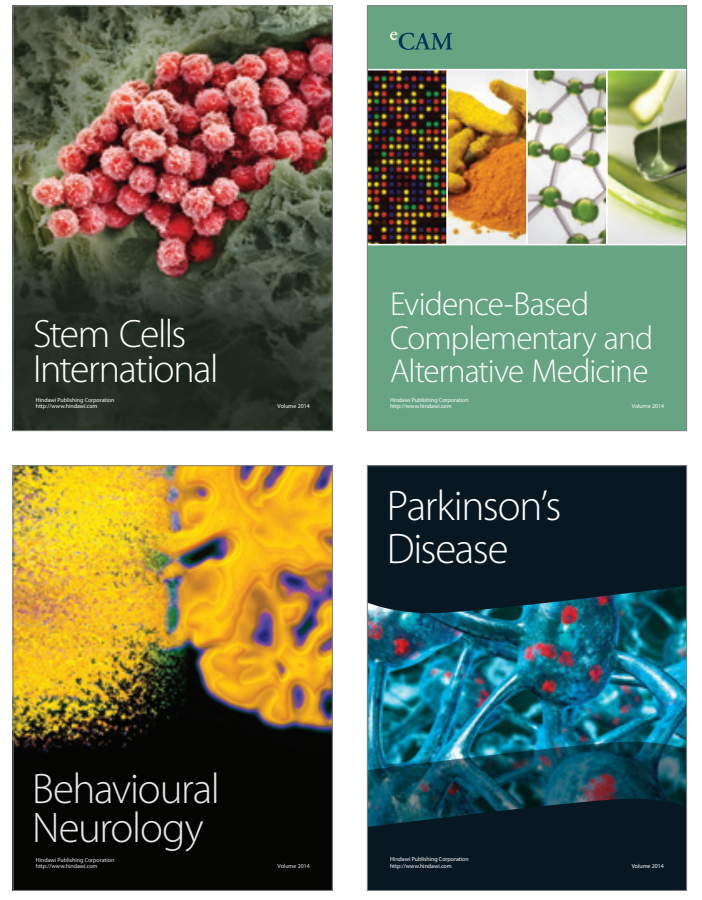
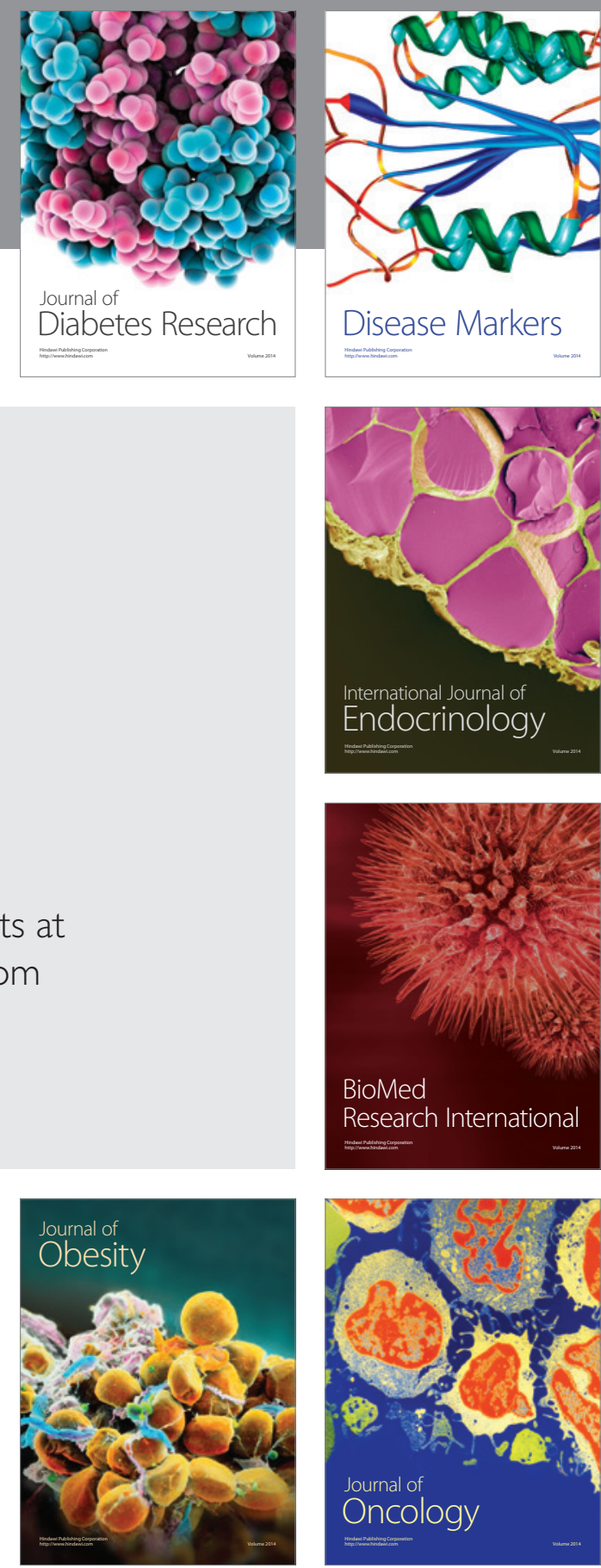

Disease Markers
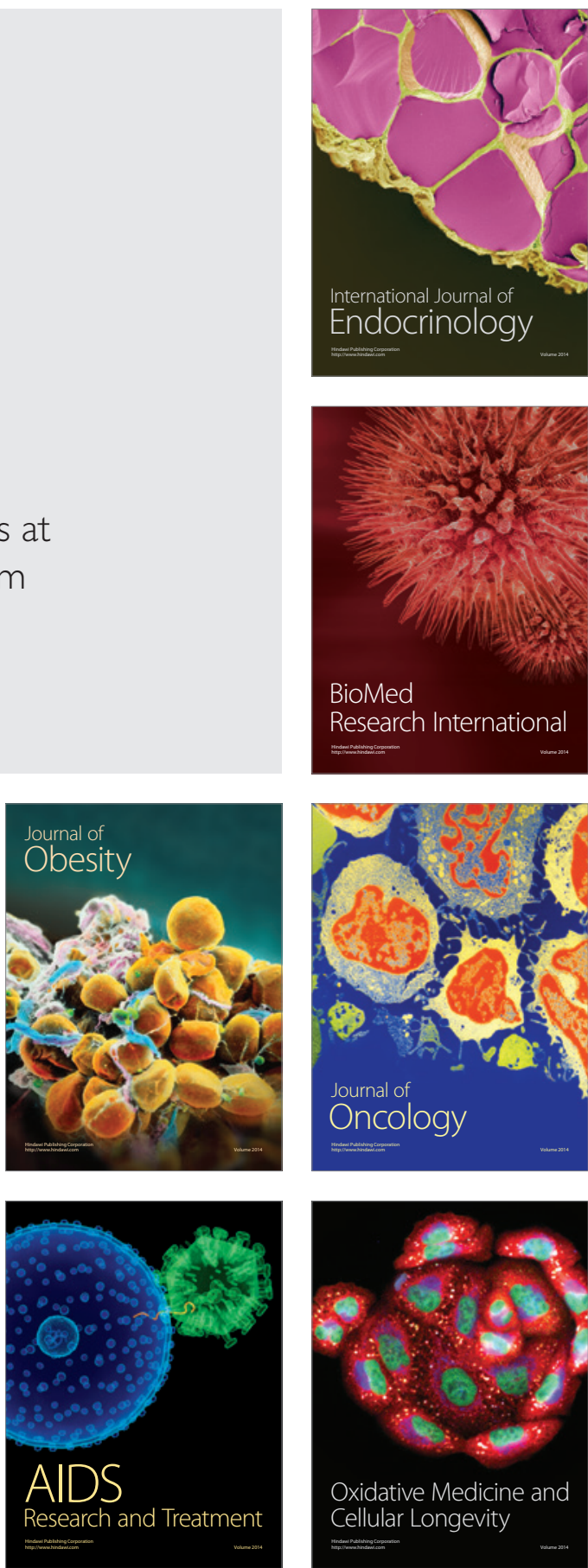